\title{
Interdependencies and Public Procurement Law. The Example of Spanish Division into Lots
}

\author{
Delia Lucía Martínez Lorenzo* \\ Centrum Overheid en Recht (CORe), Hasselt University, Martelarenlaan 42, Hasselt B-3500 Belgium
}

\begin{abstract}
Public Procurement legislation in EU countries comprises first, the EU principles of the internal market and the EU Public Procurement Package of 2014. In Spain, public procurement is regulated by the Law 9/2017 of public contracts. Two of the characteristics of the construction sector are the rigidity of sequences as well as the overlapping of operations are two elements that allow for better performance but, usually are misrepresented during the planning process of a public construction project. According to the Spanish Law of Public contracts, all projects must be divided into lots unless some -limited- circumstances concur. Additionally, all lots must render a finished outcome. This paper argues that these two elements are incompatible and proposes an alternative option that takes into account the characteristics of the construction sector and supply chain theory by dividing into processes thus reconciling the construction and public procurement sector. The research question proposed is how can a public procurement construction project be divided taking into account its inner characteristics. The methodology used is doctrinal legal research with a functional approach.
\end{abstract}

Keywords: Public Procurement, division into lots, interdependencies, construction

\section{Introduction}

The purpose of this paper is to bridge the characteristics of construction that lead to the aggregation of companies with the goals and principles of European and Spanish public procurement legislation. Taking the regulation of the division into lots as an example, the author argues that these two elements are incompatible and proposes a theoretical alternative option that integrates both construction characteristics and the legislative elements. The proposed research question (RQ) is "how can a public construction project be divided taking into account its inner characteristics according to public procurement law?".

The paper will start by addressing resource dependence theory as a mechanism to overcome uncertainty in construction. We will move then to a brief approach to public procurement legislation in the European Union. To continue with, the paper will discuss how the regulation of the division into lots in European and Spanish legislation on Public Procurement, and the challenges that the current wording of the law presents and how it limits the freedom of the economic operators to decide who they aggregate with. In the final part of this paper, a set of conclusions will be offered, merging the results from the previous sections in order to be able to set a hypothesis on how the construction sector reacts to public procurement legislation, due to its inner characteristics and to outline hot-points that call for revision.

\section{Uncertainty and resource dependence theory}

Sociologists have traditionally perceived company aggregation as driven by the need to create interdependencies to manage uncertainty (Castro, Galán, \& Casanueva, 2009; Gulati \& Gargiulo, 1999) According to Thomson (Thompson, 1967) 'uncertainty appears as the fundamental problem for complex organizations, and coping with uncertainty is the essence of the administrative process'. Translated into the construction sector, this theory provides for a reasonable explanation of the level of reliance in partnerships and subcontracting that is present in the sector (Eccles, 1981a, 1981b; Eriksson, 2007; González, Arruñada, \& Fernández, 1998). However, it seems paradoxical and unintuitive that in a sector dominated by SMEs -in the case of the European Union, $99 \%$ of the 
construction industry is comprised by SMEs, which provide for over 18 million direct jobs (EBC, 2019) a small amount of companies dominate the market, particularly in public procurement contracts (Belmonte, 2016; Castro et al., 2009).

As stated above, construction companies need to aggregate, this reality can be seen e.g. in the creation of a consortium for the development of specific projects, the use of partnerships and temporary unions, or by the mere use of subcontracting certain activities (OECD, 2010). The primary justification for this phenomena are the high level of technical specialization due to the complexity of construction projects (Kabasakal, Sözen, \& Üsdiken, 1989; Sözen, 1985; Tam, Shen, \& Kong, 2011) and interdependencies in processes and communications (Crichton, 2013; Egbu, Young, \& Torrance, 1998).

In short, a construction project is organized as a series of processes, specialised and differentiated, whose development can be performed simultaneously -overlapping of sequences- but that are dependent from each other, so the order of development cannot be altered -rigidity between sequences-(Eccles, 1981b). Combined together, all series of streams of information and its relevance in each decision of the procedure create new series of interdependencies that are expected to be established in order to overcome uncertainty.

Notwithstanding, communication channels play a key role in the development of a construction project and in the management of interdependencies (Zhang et al., 2018); hence, poor communication in the planning process may also increase uncertainty(Cheung, Yiu, \& Lam, 2013; Wong \& Lam, 2011). Regarding communication, organizational interdependencies - who does what and the established control mechanisms- should be taken into account in the design of the procurement, as they offer great opportunities for the contracting authority to increase the quality of the outcome (Walker \& Lloyd-Walker, 2016). Nevertheless, if overregulated or ignored, uncertainty and interdependencies could interfere in the performance and stability of the economic operator (Pfeffer \& Salancik, 1978).

Looking at the context of public construction projects under public procurement legislation [Public Procurement legislation regulates the acquisition of goods, services and works by a contracting authority (Arrowsmith, 2014)], the role of the contracting authority during the execution of the project and during its design may affect the aggregation level required for a project. As an example of this phenomena, the legislation on the division into lots will be briefly assessed below. Furthermore, the word of the law will be combined with the characteristics of the construction sector as well as the goals and principle of public procurement to outcast how the law when combined with a higher knowledge of the overlapping of operations; it gives a tool for the rationalization of expenses and resources and in summary: a higher public effectiveness.

\section{EU legislation}

In the European Union there is a coexistence of legislation between the supranational and national level. At the EU level, for large contracts over a pecuniary threshold we find the General Directive on Public Procurement ("Directive 2014/24/EU of the European Parliament and of the Council of 26 February 2014 on public procurement and repealing Directive 2004/18/EC Text with EEA relevance," 2014), on Concessions ("Directive 2014/23/EU of the European Parliament and of the Council of 26 February 2014 on the award of concession contracts Text with EEA relevance," 2014) and the Utilities Directive ("Directive 2014/25/EU of the European Parliament and of the Council of 26 February 2014 on procurement by entities operating in the water, energy, transport and postal services sectors and repealing Directive 2004/17/EC Text with EEA relevance," 2014).

Directives are harmonising legislative instruments that set the minimum grounds for public procurement but have to be transposed into the national legal systems. As part of the transposition process, Member States of the EU may choose to implement the directive as it is or to make modifications in order to make it stringer whenever the Directive has not fully legislated over something. Usually this is indicated in the text of the Directive by stating that 'Member States may...' instead of 'Member States shall... or must'. Nevertheless, the 
transposition of the directive must be done observing the basic principles of EU public procurement law namely non-discrimination, transparency, equal treatment and proportionality- and the goals that the directive aims to attain: [amongst others] market integration and the promotion of SMEs.

The rules pertaining to the division into lots can be found in the Directive on Public Procurement article 46 and recitals 78-79. In essence, they provide for the possibility to divide a project or desired outcome. The reasons to divide may vary from a contracting authority to another. Among the most prominent ones are the promotion of SMEs, to foster competition and a higher amount of tenderers and (in the case of supply contracts) to avoid a single supplier dependency thus spreading the risk between economic operators (Estache \& Iimi, 2011; Li, Sun, Yan, \& Yu, 2015; OECD, 2015)

As mentioned above, Directive 2014/24 allows for the division of the project into lots by contracting authorities, as well as for the reduction of the number of lots that can be awarded to one single operator. In other terms, recital 78 connects the division into lots with a need for more involvement of SMEs in public procurement (Trybus, 2014), and it establishes three options for the Member States: Extending the scope of the obligation to consider the appropriateness of dividing contracts into lots to smaller contracts; to render the division into lots obligatory under certain conditions; or, by requiring contracting authorities to provide a justification for a decision not to divide contracts into lots.

Among the reasons given in recital 78 not to divide, we can find that the contracting authority considers that that division may hindrance competition, that it will render the execution of the contract excessively technically difficult or expensive, or that the need to coordinate the different contractors for the lots could seriously risk undermining the proper execution of the contracts. Furthermore, according to recital 79, the number of lots awarded to the same economic operator as well as the number of lots an operator may tender for can be limited. Due to the risks that this may entail, the possibility to conduct a comparative assessment of the tenders by groups of lots it is included. However, this analysis must be done after determining which tender fulfil best the award criteria for each individual lot and then compared.

\section{Spanish legislation on Public Procurement}

Directive 2014/24 was transposed into the Spanish legislative system by the Ley de Contratos del Sector Público -hereinafter LCSP- ("Ley 9/2017, de 8 de noviembre, de Contratos del Sector Público, por la que se transponen al ordenamiento jurídico español las Directivas del Parlamento Europeo y del Consejo 2014/23/UE y 2014/24/UE, de 26 de febrero de 2014.," 2017). In the preamble it is stated that one of the novelties introduced will be the inversion of the previous justification for division, turning the use of lots into a requirement and its absence something to be justified. The aim of this provision is to increase the number of companies that can access to public procurement projects.

The regulation of the conditions for contracts without lots can be found under article 99, general rules - contract object. As an interesting fact, under Spanish law (art. 99.1) the object of the contract must be established but not closed to one single solution, especially those in which innovations can be used to improve efficiency and sustainability of the goods, works or services acquired. The limitation to closed solutions entails a limit to the system of division into lots, as it seems to automatically exclude the division on the basis of tasks or processes.

According to article 99.3 there are several ways to justify the absence of lots, the wording of the law includes (but not restricts to) as valid: when the division into lots may hinder competition (in which case, a previous report for the national authority of competition is required); the fact that the independent performance of the several elements included in the contract may difficult its correct execution from a technical point of view; and that the risk for the correct execution of the contract arises from the own nature of the object, requiring the 
coordination of the execution of different performances, which could be impossible if divided into lots and executed by different contractors.

Some considerations must be made. First, the object of the contract itself and its openness. As it was illustrated above, the multitude of decisions involved in the construction process give this provision a huge risk of uncertainty; moreover, from a budgeting perspective, it could be argued whether or not this provision guarantees the best value and quality for money -both goals of Spanish public procurement-.

\section{Discussion}

The arising problem of these provisions applied to the construction sector is the criteria on how to divide the lots taking into account the goals of public procurement.

If they are done by individual operational sequences, the number of possible combinations as well as individual lots might be overwhelming and cause major burdens. Nevertheless, the advantage of this separation is that it allows for branches of divisions that may include subcontracting plans. This could provide for a better inclusion of SMEs in the procedure, as well as for a more technical approach of the overlapping of sequences. Notwithstanding, the use of a division system based on functional tasks will transfer the coordination and monitoring duties from the main contractor to the contracting authority.

If on the contrary the division is made based on the value of the contract -approach that seems to be more traditional- it provides for different lots of similar value. Regardless being useful for other types of contracts, in the construction sector there is the risk that the division line does not match with the operational structure of the sequences. From the perspective of the contracting authority this provides for an easier method with a more general approach, and it allows for the minor decisions to be taken on the go. However, it is doubtful that this provides for the better execution of the contract or if it is used to create contracts that fall under a pecuniary threshold enough to leave them out of the control of competition authorities.

Considering that any regulation pertaining the division into lots would potentially affect the interaction between companies and the choice of members for the partnership, the author proposes a systematized criterion for division where the following scenarios are presented:

The first possibility focuses on the need for the division into lots - within construction- to be based on technical elements only. A technical division could also be based on processes and will allow for two types of division: simultaneous and sub sequential; with this consideration -and from a hypothetical perspective- a higher level of effectiveness can be achieved, and with it a reduction in costs from delays in the process. The downside for this approach is the need for an increased technical knowledge from the contracting authority.

A second model of division is based on the planned clusters of activities within branches of technical expertise; a detailed assessment of processes and subsequent planning that will require a higher level of definition of the activities. Gaining insights in the activities to be developed by the economic operators and understanding the level of communication and interdependencies within the actors involved. The idea is to use the tools introduced by public procurement legislation to create a map of clustered operations to be developed, and to divide the contract in these operations, opening procurement to companies of all sizes. This approach is expected to facilitate aggregation whilst still

\section{Conclusions}

The interaction between the construction sector and public procurement regulation call for a more 'construction friendly' provisions. As it has addressed above, the characteristics of the construction sector and the reliance on partnerships to overcome uncertainties may affect the division into lots. To call for a better planning the 
interaction between public procurement and construction calls for a better and more technical specialization in the procurement design.

\section{Acknowledgements}

The author would like to thank Dr. J.A.M. Dapena for its support throughout the writing process as well as for the useful exchanges of ideas that contribute to the enrichment of this paper.

\section{References}

Arrowsmith, S. (2014). The law of public and utilities procurement. Volume 1 (3rd edition ed.). London: Sweet \& Maxwell.

Belmonte, E. (2016). Los reyes del ladrillo. Retrieved from https://civio.es/quien-cobra-laobra/2016/11/15/los-reyes-del-ladrillo/

Castro, I., Galán, J., \& Casanueva, C. (2009). Antecedents of construction project coalitions: a study of the Spanish construction industry. Construction Management \& Economics, 27(9), 809-822. doi:10.1080/01446190903117751

Cheung, S. O., Yiu, T. W., \& Lam, M. C. (2013). Interweaving Trust and Communication with Project Performance. Journal of Construction Engineering \& Management, 139(8), 941-950. doi:10.1061/(ASCE)CO.1943-7862.0000681

Crichton, C. (2013). Interdependence and Uncertainty: A study of the building industry: Routledge.

Directive 2014/23/EU of the European Parliament and of the Council of 26 February 2014 on the award of concession contracts Text with EEA relevance, (2014).

Directive 2014/24/EU of the European Parliament and of the Council of 26 February 2014 on public procurement and repealing Directive 2004/18/EC Text with EEA relevance, (2014), http://data.europa.eu/eli/dir/2014/24/oj.

Directive 2014/25/EU of the European Parliament and of the Council of 26 February 2014 on procurement by entities operating in the water, energy, transport and postal services sectors and repealing Directive 2004/17/EC Text with EEA relevance, (2014).

EBC. (2019). EBC Manifesto 2019-2024 Empowering construction SMEs to build a sustainable Europe.

Eccles, R. G. (1981a). Bureaucratic versus Craft Administration: The Relationship of Market Structure to the Construction Firm. Administrative Science Quarterly, 26(3), 449-469.

Eccles, R. G. (1981b). The quasifirm in the construction industry. Journal of Economic Behavior \& Organization, 2(4), 335-357. doi:https://doi.org/10.1016/0167-2681(81)90013-5

Egbu, C. O., Young, B. A., \& Torrance, V. B. (1998). Planning and control processes and techniques for refurbishment management. Construction Management \& Economics, 16(3), 315-325. doi:10.1080/014461998372349

Eriksson, E. (2007). The influence of partnering and procurement on subcontractor involvement and innovation. Facilities, 25(5/6), 203-216.

Estache, A., \& Iimi, A. (2011). (Un) bundling infrastructure procurement: Evidence from water supply and sewage projects. Utilities policy, 19(2), 104-114.

González, M., Arruñada, B., \& Fernández, A. (1998). Regulation as a cause of firm fragmentation:the case of the Spanish construction industry. International Review of Law and Economics, 18(4), 433-450. doi:https://doi.org/10.1016/S0144-8188(98)00019-2

Gulati, R., \& Gargiulo, M. (1999). Where Do Interorganizational Networks Come From? American Journal of Sociology, 104(5), 1439-1493. doi:10.1086/210179 
Kabasakal, H. E., Sözen, Z., \& Üsdiken, B. (1989). Organizational context, structural attributes and management systems in construction firms. Construction Management \& Economics, 7(4), 347. doi:10.1080/01446198900000033

Li, S., Sun, H., Yan, J., \& Yu, J. (2015). Bundling decisions in procurement auctions with sequential tasks. Journal of Public Economics, 128, 96-106.

OECD. (2010). Construction Industry. doi:doi:https://doi.org/10.1787/clp-10-5kmhbhp87tbv

OECD. (2015). Competition and the use of tenders and auctions.

Pfeffer, J., \& Salancik, G. R. (1978). The external control of organizations : a resource dependence perspective. New York: Harper \& Row.

Sözen, Z. (1985). Size, technology and aspects of structure in contractor firms in Turkey. Construction Management \& Economics, 3(3), 233. doi:10.1080/01446198500000017

Tam, V. W. Y., Shen, L. Y., \& Kong, J. S. Y. (2011). Impacts of multi-layer chain subcontracting on project management performance. International Journal of Project Management, 29(1), 108-116. doi:https://doi.org/10.1016/j.ijproman.2010.01.005

Thompson, J. D. (1967). Organizations in action : social science bases of administrative theory. New York: McGraw-Hill.

Trybus, M. (2014). The Promotion of Small and Medium Sized Enterprises in Public Procurement: a Strategic Objective of the New Public Sector Directive? Chapter in François Lichère, Roberto Caranta and Steen Treumer (eds.) Modernising Public Procurement: The New Directive (Djøf: Copenhagen, 2014), at, 255-280.

Walker, D., \& Lloyd-Walker, B. (2016). Understanding Collaboration in Integrated Forms of Project Delivery by Taking a Risk-Uncertainty Based Perspective. Administrative Sciences, 6(3), 10. doi:10.3390/admsci6030010

Wong, F. W. H., \& Lam, P. T. I. (2011). Difficulties and Hindrances Facing End Users of Electronic Information Exchange Systems in Design and Construction. Journal of Management in Engineering, 27(1), 2839. doi:10.1061/(ASCE)ME.1943-5479.0000028

Zhang, Q., Tang, W., Liu, J., Duffiel, C. F., Hui, F. K. P., Zhang, L., \& Zhang, X. (2018). Improving Design Performance by Alliance between Contractors and Designers in International Hydropower EPC Projects from the Perspective of Chinese Construction Companies. Sustainability, 10(4), 1171. 